\title{
EKSTRAKSI KALIUM DARI ABU KULIT BUAH KELAPA (Cocos Nucifera L.) MENGGUNAKAN PELARUT AQUADEST
}

\author{
EXTRACTION POTASSIUM FROM COCONUT PEEL ASH (Cocos Nucifera L.) BY \\ USING AQUADEST AS SOLVENT
}

\author{
Gilang Ramadhan*, Lilis Sukeksi \\ Departemen Teknik Kimia, Fakultas Teknik, Universitas Sumatera Utara, \\ Jalan Almamater, Medan, 20155, Indonesia \\ *Email: ramadhangilang95@gmail.com
}

\begin{abstract}
Abstrak
Pada penelitian ini, proses pembakaran dilakukan secara konvensional dengan membakar kulit buah kelapa yang telah dikeringkan sebanyak $10 \mathrm{~kg}$ di dalam tong pembakaran yang tertutup, dilengkapi termometer gauge dan telah dilubangi untuk ruang masuk oksigen proses ini berlangsung selama 3 jam dengan suhu pembakaran berkisar $500^{\circ} \mathrm{C}$ dan dihasilkan abu kulit buah kelapa sebanyak $1 \mathrm{~kg}$. Ekstraksi dilakukan dengan dengan mencampurkan abu kulit buah kelapa dan pelarut aquadest dengan kecepatan pengadukan $250 \mathrm{rpm}$, variasi waktu 40 menit, 80 menit, 120 menit, dan 160 menit dengan suhu $60^{\circ} \mathrm{C}$ dan $80^{\circ} \mathrm{C}$. Rasio massa abu : pelarut adalah 5:50, 10:50, 15:50, dan 20:50. Hasil yang diperoleh menunjukkan bahwa semakin besar massa, suhu dan waktu ekstraksi maka didapatkan konsentrasi dan $\mathrm{pH}$ ekstrak alkali semakin tinggi pula. Konsentrasi dan $\mathrm{pH}$ ekstrak alkali tertinggi diperoleh pada rasio massa abu:pelarut adalah 20:50 selama waktu ekstraksi 160 menit pada suhu $80^{\circ} \mathrm{C}$ yaitu $0,775 \mathrm{~N}$ dan 13.
\end{abstract}

Kata kunci: abu kulit buah kelapa, ekstraksi, kalium, konvensional

\begin{abstract}
In this research, the combustion process was performed conventionally by burning the dried coconut peel of $10 \mathrm{~kg}$ in a covered combustion barrel, equipped with a gauge thermometer and having been perforated for the oxygen entrance space for 3 hours with a combustion temperature ranging $500^{\circ} \mathrm{C}$ and produced ash of coconut peel as much as $1 \mathrm{~kg}$. Extraction was performed by mixing biphasic system between coconut peel ash and aquadest solvent at stirring rate of $250 \mathrm{rpm}$, variation of time are 40 minutes, 80 minutes, 120 minutes, and 160 minutes with temperatures of $60^{\circ} \mathrm{C}$ and $80^{\circ} \mathrm{C}$. Ash mass ratio: solvent are 5:50, 10:50, 15:50, and 20:50. Results showed that the geater the mass, temperature and extraction time, the higher concentration and $\mathrm{pH}$ of alkali extract will be obtained. The concentration and $\mathrm{pH}$ of the highest alkali extract were obtained at the ratio of the ash mass: the solvent was 20:50 for the extraction time of 160 minutes at a temperature of $80^{\circ} \mathrm{C}$ those are $0.775 \mathrm{~N}$ and 13 .
\end{abstract}

Keywords: coconut peel ash, extraction, potassium, conventional

\section{Pendahuluan}

Negara-negara agraris umumnya mempunyai masalah terhadap limbah hasil pertanian karena terbatasnya tempat pembuangan limbah tersebut [16]. Limbah pertanian dapat berbentuk bahan buangan yang tidak terpakai dan bahan sisa dari hasil pengolahan. Proses penghancuran limbah secara alami berlangsung lambat, sehingga tumpukan limbah tersebut dapat menganggu lingkungan [15]. Selain itu, penghancuran limbah akan menimbulkan biaya seperti pembakaran limbah tersebut.

Produksi kelapa di Sumatera Utara adalah 88.962 ton, dengan produksi terbesar dari Kabupaten Nias Utara 14.905 ton, Asahan 18.121 ton dan Nias Selatan 12,612 ton. Dengan jumlah produksi kelapa tersebut, diperoleh jumlah produksi ampas kelapa di provinsi Sumatera Utara sebesar $13.344 .300 \mathrm{~kg}$ [6].
Kulit buah kelapa (cocos nucifera l.) merupakan bagian kelapa yang belum dimanfaatkan secara maksimal karena selama ini dalam rumah tangga hanya mengambil santan buah kelapa saja sehingga biasanya kulit buah kelapa dibuang begitu saja atau terkadang digunakan sebagai alat bakar. Abu hasil pembakaran kulit buah kelapa memiliki senyawa utama kadar ion kalium $(\mathrm{K})$ dan karbonat $\left(\mathrm{CO}_{3}\right)$ yang tinggi masing-masing 40 dan 27,7 \% [12].

Kelapa memiliki potensi besar sebagai sumber ekonomis kaustik kalium dengan cara mengekstrak garam kalium dari kulit kelapa. Kulit kelapa memiliki kandungan kalium sekitar $40 \%$ dari abunya [12]. Dalam hal ini kulit buah kelapa dapat dimanfaatkan menjadi alkali yang dibakar dahulu menjadi abu. 


\section{Teori}

Buah kelapa terdiri dari beberapa bagian, yaitu kulit luar, sabut, tempurung, kulit daging buah, daging buah, air kelapa dan lembaga. Sabut kelapa merupakan hasil samping, dan merupakan bagian yang terbesar dari buah kelapa, yaitu sekitar $35 \%$ dari bobot buah kelapa yang merupakan sisa buah kelapa yang banyak terdapat di Indonesia. Bagian yang berserabut merupakan kulit dari buah kelapa. Dengan demikian, apabila secara rata-rata produksi buah kelapa per tahun adalah sebesar 5,6 juta ton, maka berarti terdapat sekitar 1,7 juta ton sabut kelapa yang dihasilkan [9].

Kulit buah kelapa merupakan bagian kelapa yang belum di manfaatkan secara maksimal karena selama ini dalam rumah tangga hanya mengambil santan buah kelapa saja sehingga biasanya kulit buah kelapa dibuang begitu saja atau terkadang digunakan sebagai alat bakar. Abu hasil pembakaran kulit buah kelapa memiliki senyawa utama kadar ion kalium (K) dan karbonat $\left(\mathrm{CO}_{3}\right)$ yang tinggi masing-masing 40 dan 27,7\% [12].

Pembakaran adalah sebuah fenomena kompleks antara hubungan simultan perpindahan panas dan perpindahan massa dengan reaksi kimia dan aliran fluida [2]. Abu merupakan bahan anorganik yang tidak dapat dibakar dari sumber bahan bakar yang tersisa setelah melalui pembakaran sempurna dan mengandung fraksi mineral dari biomassa tersebut [1]. Faktor-faktor atau kondisi yang mempengaruhi proses dekarbonisasi adalah sebagai berikut:

a. Waktu berpengaruh pada produk yang akan dihasilkan karena semakin lama waktu proses pirolis berlangsung, produk yang dihasilkan (residu padat, tar, dan gas) semakin naik.

b. Suhu sangat mempengaruhi produk yang dihasilkan karena sesuai dengan persamaan Arrchenius yang menyatakan suhu semakin tinggi nilainya konstanta dekomposisi termal semakin besar akibatnya laju pirolisis bertambah dan konversi naik [5].

c. Kadar air dengan umpan besar sekali pengaruhnya. Hal ini disebabkan karena uap air yang diusir makin banyak. Kadar air untuk bermacam-macam zat tidak sama.

d. Ukuran bahan berpengaruh sekali pada perataan panas. Makin kecil ukuran bahan makin cepat perataan keseluruhan umpan sehinggal pirolisis berjalan lebih sempurna [10].

\section{Metodologi Penelitian \\ Bahan Baku dan Peralatan}

Bahan yang digunakan dalam penelitian ini adalah kulit buah kelapa sebagai bahan baku, aquadest, larutan $\mathrm{HCl}$, dan juga digunakan indikator phenolphthalein.

Alat yang digunakan meliputi tong pembakaran sebagai tempat pembakaran sampel, neraca analitik untuk mengukur massa bahan, Beaker glass sebagai wadah untuk mengekstrak abu, gelas ukur untuk mengukur volume larutan, Corong untuk membantu menuang larutan, statif dan klem, buret sebagai alat titrasi, pipet tetes untuk mengambil larutan dalam jumlah kecil, erlenmeyer sebagai wadah titrasi, stopwatch untukmengukur waktu ekstraksi, kertas saring sebagai alat pemisah filtrat dan residu.

\section{Prosedur Pembuatan Abu}

Pada proses pembuatan abu, kulit buah kelapa dibakar secara langsung ataupun secara konvensional, kulit buah kelapa dimasukkan ke dalam tong pembakaran yang telah dilengkapi termometer gauge dan telah dilubangi untuk ruang masuk oksigen selama proses pembakaran berlangsung, kemudian dibakar, proses pembakaran berlangsung secara tertutup. Suhu pada proses pembakaran mencapai $500^{\circ} \mathrm{C}$ dan berlangsung selama 3 jam hingga menghasilkan abu kulit buah kelapa.

\section{Proses Ekstraksi Abu}

Abu ditimbang sebanyak $5 \mathrm{~g}, 10 \mathrm{~g}, 15 \mathrm{~g}$, dan $20 \mathrm{~g}$ untuk 4 (empat) labu leher satu yang dilengkapi magnetic stirrer. Pelarut air ditambahkan sebanyak $50 \mathrm{ml}$ kedalam labu leher satu. Labu ditutup dengan gabus dan dilengkapi termometer. Campuran dipanaskan dengan hot plate pada suhu $60^{\circ} \mathrm{C}$ dan $80^{\circ} \mathrm{C}$ selama 40 menit, 80 menit, 120 menit, dan 160 menit dengan kecepatan $250 \mathrm{rpm}$. Campuran disaring dengan kertas saring whatman no 41 .

\section{Hasil Dan Pembahasan \\ Kadar Abu Kulit Buah Kelapa}

Kulit buah kelapa yang digunakan dalam penelitian ini adalah kulit buah kelapa yang diperoleh dari pemarut kelapa di Pasar Pangkalan Susu dan Hamparan Perak, Provinsi Sumatera Utara.

Kulit buah kelapa dikeringkan terlebih dahulu selama 1 x 24 jam untuk mengurangi kadar air yang ada dalam kulit buah kelapa dari berat awal $10 \mathrm{~kg}$ menjadi $8 \mathrm{~kg}$, lalu ukurannya diperkecil dengan memotong menjadi ukuaran yang sama besar. Tujuan dilakukannya pengecilan ukuran bahan agar proses pembakarannya lebih efektif. Ukuran partikel bahan berpengaruh sekali pada perataan panas. Makin kecil ukuran bahan makin cepat perataan keseluruhan umpan sehingga proses akan berlangsung lebih cepat [3]. 
Pada percobaan ini kulit buah kelapa dibakar secara langsung ataupun secara konvensional sebagai bentuk dari pengimplementasian, kulit buah kelapa dimasukkan ke dalam tong pembakaran yang telah dilengkapi termometer gauge dan telah dilubangi untuk ruang masuk oksigen selama proses pembakaran berlangsung, kemudian dibakar, proses pembakaran berlangsung secara tertutup. Suhu pada proses pembakaran mencapai $500^{\circ} \mathrm{C}$ dan berlangsung selama 3 jam hingga menghasilkan abu kulit buah kelapa.

Sebelum dilakukan pengeringan kulit buah kelapa $10 \mathrm{~kg}$, setelah dilakukan pengeringan diperoleh menjadi $8 \mathrm{~kg}$, dengan demikian terdapat 20\% kadar air dalan kulit buah kelapa. Pengeringan dapat diartikan sebagai usaha mengurangi kadar air bahan sampai batas aman untuk disimpan. Pada saat keadaan kadar air bahan setimbang, proses pengeringan akan berhenti karena air yang terdapat di dalam bahan tidak mampu lagi menguap [14].
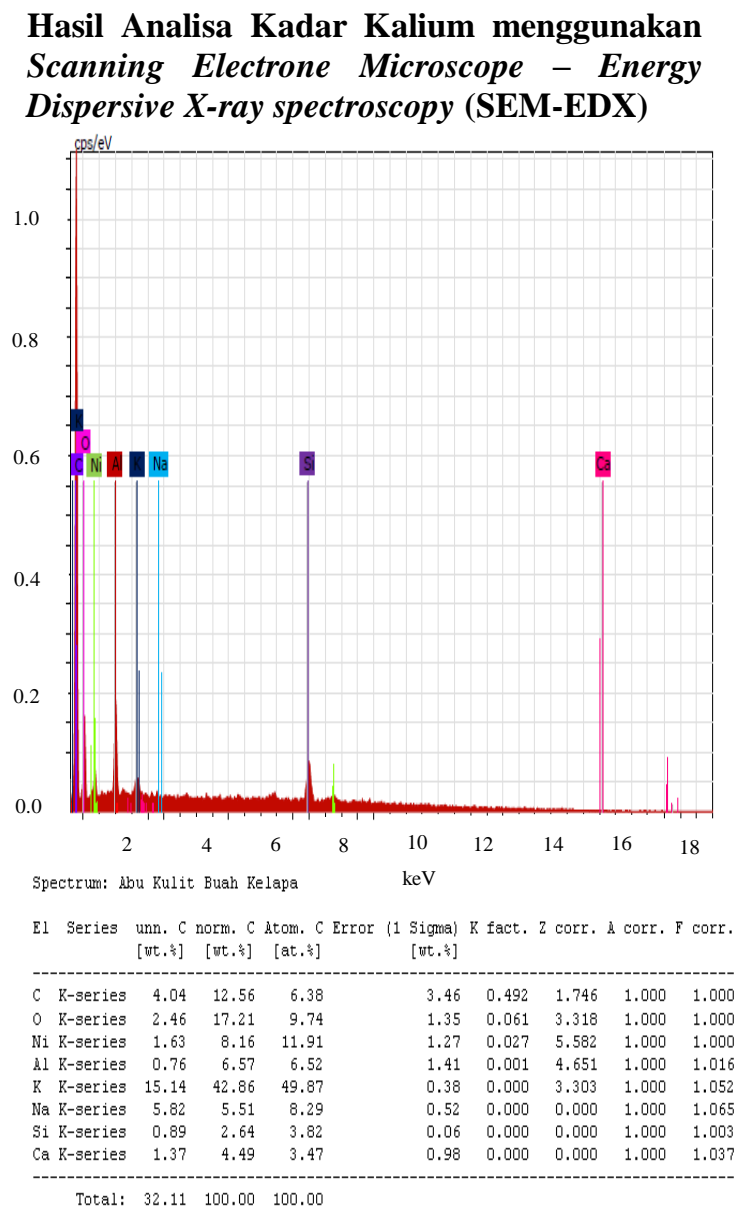

Gambar 1. Hasil Analisa Kandungan Kalium dengan Scanning Electrone Microscope Energy Dispersive X-ray spectroscopy (SEMEDX)
Pada penelitian yang telah dilakukan, ekstrak abu kulit buah kelapa dianalisis dengan Scanning Electrone Microscope - Energy Dispersive $X$-ray spectroscopy (SEM-EDX) untuk mengetahui kandungan kalium, dan hasilnya diberikan pada gambar 1 .

Pengaruh Variasi Massa abu, Suhu dan Waktu Ekstraksi terhadap pH Ekstrak Alkali

Hasil berikut memperlihatkan pengaruh dari variasi massa abu, suhu dan waktu ekstraksi terhadap $\mathrm{pH}$ ekstrak yang dihasilkan dari abu kulit buah kelapa dapat dilihat pada gambar 2 .

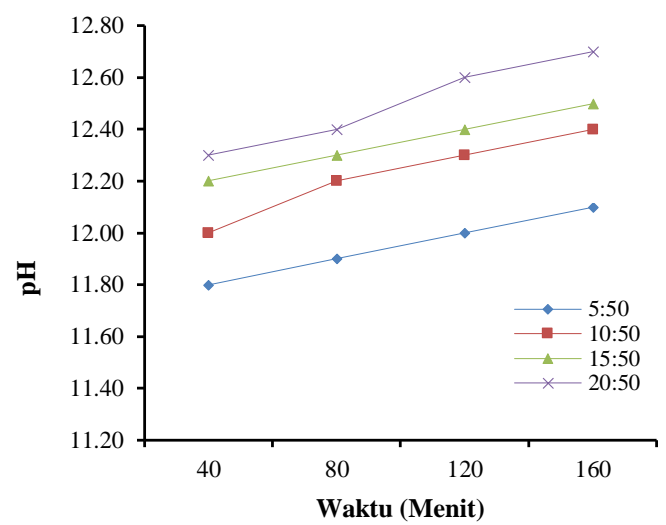

(a)

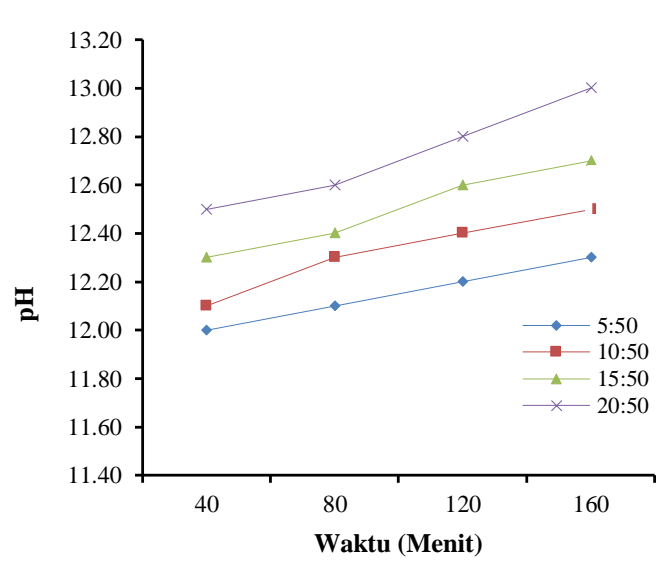

(b)

Gambar 2. Pengaruh Massa abu, Suhu dan Waktu Ekstraksi terhadap pH Ekstrak Alkali (a) Suhu $6^{\circ} \mathrm{C}$ dan (b) Suhu $80^{\circ} \mathrm{C}$

Dari gambar 2 (a) dan (b) menunjukkan hubungan massa abu, suhu dan waktu ekstraksi terhadap $\mathrm{pH}$ ekstrak yang dihasilkan. Pada suhu $60^{\circ} \mathrm{C}$ diperoleh nilai $\mathrm{pH}$ tertinggi yaitu pada rasio 20/50 nilai $\mathrm{pH} 12,7$; sedangkan $\mathrm{pH}$ terendah yaitu pada rasio $5 / 50$ nilai $\mathrm{pH} 11,8$. Pada suhu $80^{\circ} \mathrm{C}$ diperoleh nilai $\mathrm{pH}$ tertinggi yaitu pada rasio 
20/50 nilai $\mathrm{pH} 13,0$; sedangkan $\mathrm{pH}$ terendah yaitu pada rasio $5 / 50$ nilai $\mathrm{pH} 12,0$.

Dari gambar 2 dapat dilihat bahwa semakin tinggi suhu dan semakin lama waktu ekstraksi dari abu kulit buah kelapa maka nilai $\mathrm{pH}$ yang dihasilkan akan cenderung meningkat.

Perpindahan massa antar fase terjadi bila terdapat perbedaan konsentrasi dimana berpindah dari sistem yang lebih tinggi konsentrasinya ke sistem yang lebih rendah konsentrasinya [11]. Meratanya distribusi pelarut ke padatan juga akan memperbesar rendemen yang dihasilkan [7]. Semakin banyaknya perpindahan massa yang terjadi pada sampel dengan mineral yang bersifat basa akan meningkatkan $\mathrm{pH}$ dari ekstrak yang dihasilkan karena mineral seperti kalium dan natrium yang terdapat pada abu akan terlarut dalam pelarut membentuk kalium hidroksida atau natrium hidroksida yang bersifat basa.

Semakin tinggi suhu dan semakin lama waktu ekstraksi dari abu kulit buah kelapa maka nilai pH yang dihasilkan akan cenderung meningkat. Kecenderungan semakin meningkatnya $\mathrm{pH}$ seiring dengan naiknya suhu pemanasan disebabkan oleh naiknya energi panas yang terdapat pada pelarut (air) sehingga akan semakin banyak melarutkan komponen kimia pada abu kulit buah kelapa yang bersifat basa. Semakin tinggi suhu, proses ekstraksi akan semakin cepat dan hasil ekstraksi akan semakin banyak.

Pengaruh Variasi Massa, Suhu dan Waktu Ekstraksi terhadap Konsentrasi Ekstrak Alkali

Hasil berikut memperlihatkan pengaruh dari variasi massa abu, suhu dan waktu ekstraksi terhadap konsentrasi alkali yang dihasilkan dari ekstraksi abu kulit buah kelapa dapat dilihat pada gambar 3.

Dari gambar 3 (a) dan (b) menunjukkan hubungan massa abu, suhu dan waktu ekstraksi terhadap konsentrasi ekstrak yang dihasilkan. Pada suhu $60^{\circ} \mathrm{C}$ diperoleh nilai konsentrasi tertinggi yaitu pada rasio 20/50 nilai konsentrasi $0,525 \mathrm{~N}$; sedangkan konsentrasi terendah yaitu pada rasio 5/50 nilai konsentrasi 0,125 N. Pada suhu $80^{\circ} \mathrm{C}$ diperoleh nilai konsentrasi tertinggi yaitu pada rasio 20/50 nilai konsentrasi $0,775 \mathrm{~N}$; sedangkan konsentrasi terendah yaitu pada rasio $5 / 50$ nilai konsentrasi $0,275 \mathrm{~N}$.

Dari gambar 3 dapat dilihat bahwa semakin tinggi suhu dan semakin lama waktu ekstraksi dari abu kulit buah kelapa maka nilai konsentrasi yang dihasilkan akan semakin meningkat.

Dari gambar 3 (a) dan (b) tersebut dapat dilihat adanya pengaruh massa abu dan waktu ekstraksi terhadap konsentrasi dari ekstrak. Dengan semakin bertambahnya jumlah abu yang digunakan menyebabkan nilai konsentrasi dari ekstrak yang dihasilkan pun menjadi ikut meningkat.

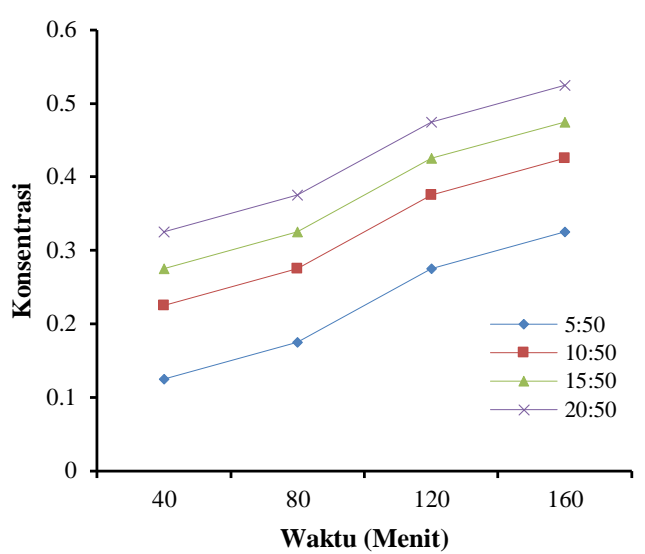

(a)

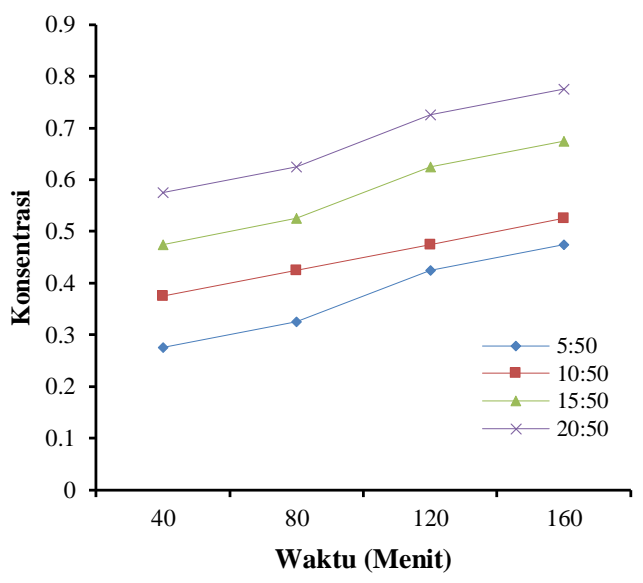

(b)

Gambar 3. Pengaruh Massa abu, Suhu dan Waktu Ekstraksi terhadap Konsentasi Ekstrak Alkali (a) Suhu $60^{\circ} \mathrm{C}$ dan (b) Suhu $8^{\circ} \mathrm{C}$

Saat terjadi kontak antara padatan dengan pelarut, sebagian solute akan berpindah ke dalam solvent dan terbentuklah larutan. Perpindahan solute tersebut dapat terjadi karena adanya perbedaan konsentrasi solute dalam larutan dan dalam padatan. Perbedaan konsentrasi ini akan menjadi driving force terjadinya proses ekstraksi. Perpindahan solute akan terjadi hingga dicapai keadaan setimbang [13]. Kemudian dengan semakin lama waktu ekstraksi, maka konsentrasi ekstrak akan meningkat. Karena semakin lama waktu ekstraksi kuantitas bahan yang terekstrak 
juga akan semakin meningkat dikarenakan kesempatan untuk bersentuhan anatara bahan dengan pelarut makin besar sehingga hasilnya akan bertambah [4].

Semakin tinggi suhu ekstraksi, maka semakin banyak alkali yang dapat terlarut. Semakin tinggi suhu ekstraksi maka konversi akan semakin tinggi. Proses ekstraksi adalah suatu aplikasi dari proses perpindahan massa, suhu merupakan salah satu faktor yang mempengaruhi kecepatan perpindahan massa. Peningkatan suhu dapat menyebabkan peningkatan solubilitas pelarut dan dapat memperbesar pori padatan, sehingga pelarut masuk melalui pori-pori padatan dan melarutkan komponen padatan yang terjerap kemudian zat terlarut berdifusi keluar permukaan partikel padatan dan bergerak ke lapisan film sekitar padatan, selanjutnya ke larutan [7]

\section{Hubungan Konsentrasi Terhadap pH pada Suhu $60^{\circ} \mathrm{C}$}

Hasil berikut memperlihatkan hubungan konsentrasi terhadap pH dari ekstraksi abu kulit buah kelapa dapat dilihat pada gambar 4 .

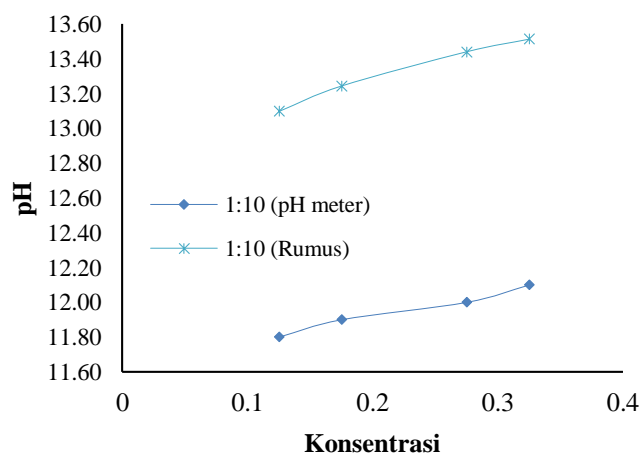

(a)

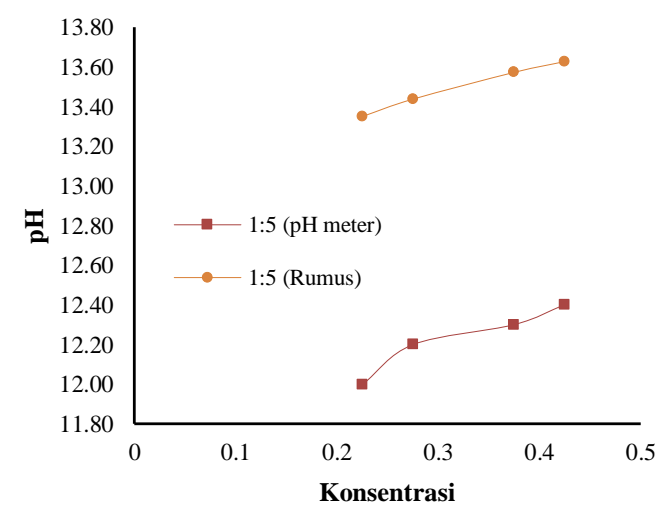

(b)

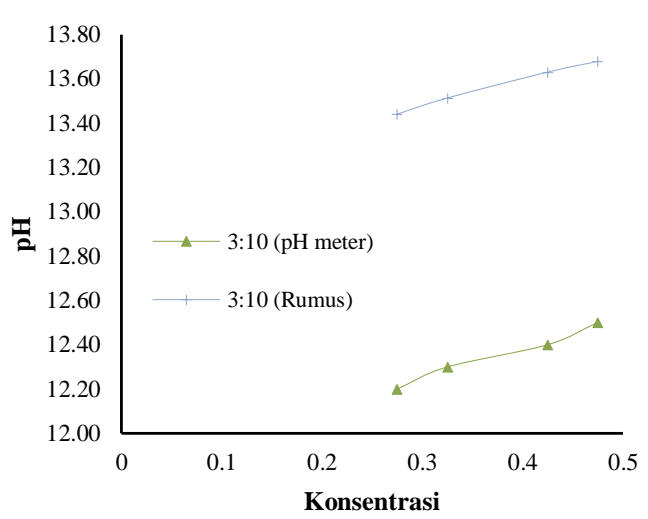

(c)

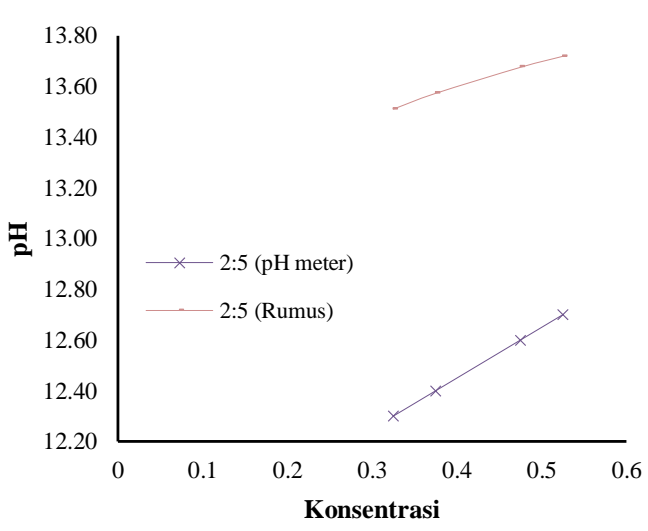

(d)

Gambar 4. Hubungan Konsentrasi Terhadap pH pada suhu $60^{\circ} \mathrm{C}$ antara $\mathrm{pH}$ yang diukur menggunakan $\mathrm{pH}$ meter dengan rumus (a) Rasio 1:10 (b) Rasio 1:5 (c) 3:10 dan (d) 2:5

Gambar 4 (a), (b), (c) dan (d) menunjukkan hubungan konsentrasi terhadap $\mathrm{pH}$ yang didapat secara $\mathrm{pH}$ meter dan rumus konsentrasi. Pada suhu $60^{\circ} \mathrm{C}$ diperoleh konsentrasi dan $\mathrm{pH}$ tertinggi yaitu pada rasio $2 / 5$ dengan nilai konsentrasi $0,525 \mathrm{~N}$ nilai $\mathrm{pH}$ pada $\mathrm{pH}$ meter dan berdasarkan rumus normalitas sebesar 12,7 dan 13,7201; sedangkan konsentrasi dan $\mathrm{pH}$ terendah yaitu pada rasio 1/10 dengan nilai konsentrasi $0,125 \mathrm{~N}$ nilai $\mathrm{pH}$ pada $\mathrm{pH}$ meter dan berdasarkan rumus normalitas sebesar 11,8 dan 13,0969.

$\mathrm{pH} \quad=14-\mathrm{pOH}$

$\mathrm{pOH}=-\log \left[\mathrm{OH}^{-}\right]$

Semakin besar konsentrasi maka $\mathrm{pH}$ yang dihasilkan juga semakin tinggi, dari gambar 4 dapat dilihat bahwa semakin tinggi konsentrasi maka pH juga semakin bertambah besar. Terdapat perbedaan nilai $\mathrm{pH}$ antara yang 
menggunakan $\mathrm{pH}$ meter dengan rumus konsentrasi, hal ini disebabkan oleh perbedaan basis yang digunakan dalam perhitungan $\mathrm{pH}$.

\section{Hubungan Konsentrasi Terhadap pH pada Suhu $8^{\circ} \mathrm{C}$}

Hasil berikut memperlihatkan hubungan konsentrasi terhadap $\mathrm{pH}$ dari ekstraksi abu kulit buah kelapa dapat dilihat pada gambar 5 .

Gambar 5 (a), (b), (c) dan (d) menunjukkan hubungan konsentrasi terhadap $\mathrm{pH}$ yang didapat secara $\mathrm{pH}$ meter dan rumus konsentrasi. Pada suhu $80^{\circ} \mathrm{C}$ diperoleh konsentrasi dan $\mathrm{pH}$ tertinggi yaitu pada rasio 2/5 dengan nilai konsentrasi $0,775 \mathrm{~N}$ nilai $\mathrm{pH}$ pada $\mathrm{pH}$ meter dan berdasarkan rumus normalitas sebesar 13,0 dan 13,8893; sedangkan konsentrasi dan $\mathrm{pH}$ terendah yaitu pada rasio 1/10 dengan nilai konsentrasi $0,275 \mathrm{~N}$ nilai $\mathrm{pH}$ pada $\mathrm{pH}$ meter.

Berdasarkan rumus normalitas sebesar 12,0 dan $13,4393$.

$\mathrm{pH}=14-\mathrm{pOH}$

[8]

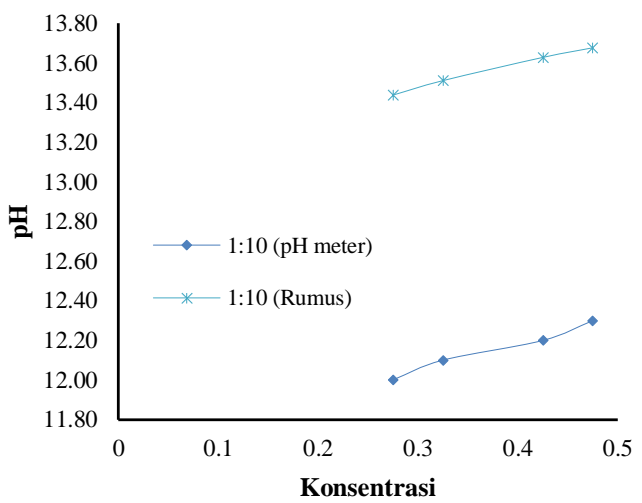

(a)

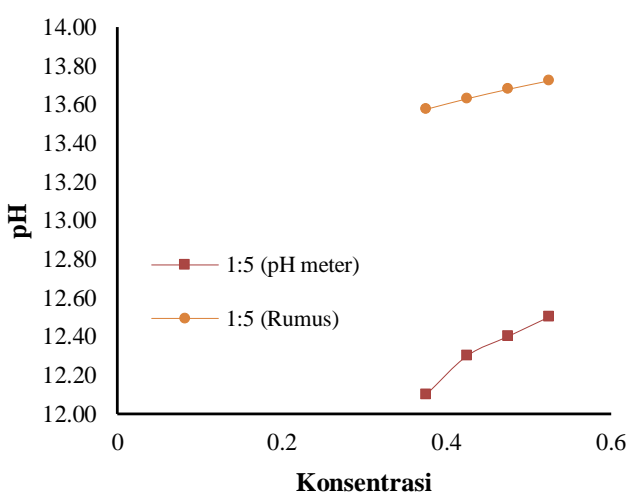

(b)

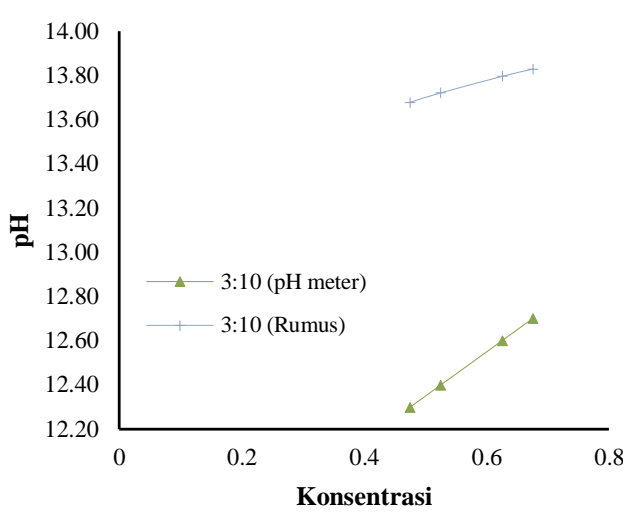

(c)

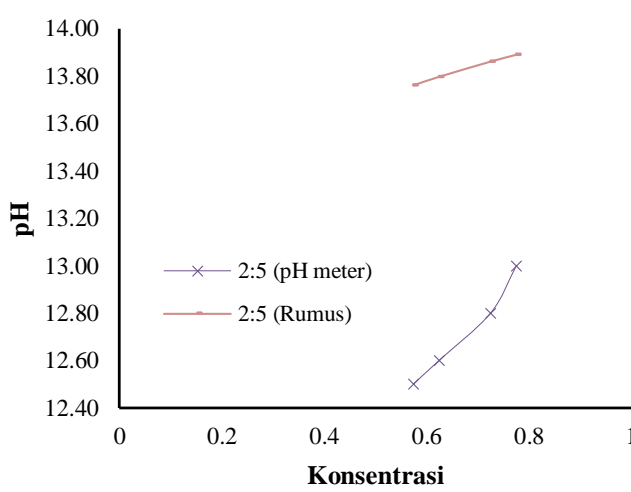

(d)

Gambar 5. Hubungan Konsentrasi Terhadap pH pada suhu $80^{\circ} \mathrm{C}$ antara $\mathrm{pH}$ yang diukur menggunakan $\mathrm{pH}$ meter dengan rumus (a) Rasio 1:10 (b) Rasio 1:5 (c) 3:10 dan (d) 2:5

Semakin besar konsentrasi maka $\mathrm{pH}$ yang dihasilkan juga semakin tinggi, dari gambar 5 dapat dilihat bahwa semakin tinggi konsentrasi maka pH juga semakin bertambah besar. Terdapat perbedaan nilai $\mathrm{pH}$ antara yang menggunakan $\mathrm{pH}$ meter dengan rumus konsentrasi, hal ini disebabkan oleh perbedaan basis yang digunakan dalam perhitungan $\mathrm{pH}$.

\section{Kesimpulan}

Adapun kesimpulan yang dapat ditarik dari penelitian ini antara lain :

1. Hasil analisa $\mathrm{pH}$ ekstrak abu diperoleh $\mathrm{pH}$ tertinggi sebesar 13 yang menunjukkan bahwa hasil bersifat basa.

2. Konsentrasi alkali dari abu ekstraksi abu kulit buah kelapa tertinggi diperoleh pada massa 
abu $20 \mathrm{~g}$, suhu ekstraksi $80^{\circ} \mathrm{C}$ dan waktu ekstraksi 160 menit sebesar $0,775 \mathrm{~N}$.

3. Hasil analisa ekstrak abu kulit buah kelapa menggunakan SEM-EDX diperoleh kandungan kalium sebesar 42,86 \%.

4. Kandungan kalium pada abu kulit buah kelapa dapat digunakan sebagai sumber larutan alkali dalam pembuatan sabun.

\section{Daftar Pustaka}

[1] A. Khan, Jong, W. Jansens, P. Spliethoff, Biomass combustion in fluidized bed boilers: Potential problems and remidies. Fuel Process. Technol, 90, (2009) 21-50.

[2] B. M. Jenkins, L. L. Baxter, T. R. Miles, Combustion Properties of Biomass, Fuel Processing Technology 54, 17-46, Elsevier Sciences, 1998.

[3] E. Kurniati, Pemanfaatan Cangkang Kelapa Sawit Sebagai Arang Aktif, Jurnal Penelitian Ilmu Teknologi, Vol. 8, no. 2, (2008) pp. 96-103.

[4] F. Diantika, S. M. Sutan, R. Yulianingsih, Pengaruh Lama Ekstraksi dan Konsentrasi Pelarut Etanol Terhadap Ekstraksi Antioksidan Biji Kakao (Theobroma Cacao L.), Vol. 15, no. 3, 2014, pp. 159-164.

[5] I. Lufina, B. Susilo dan R. Yulianingsih, Studi Pemanfaatan Minyak Karet (Hevea Brasiliensis) sebagai Bahan Bakar pada Kompor Rumah Tangga, Jurnal Keteknikan Pertanian Tropis dan Biosistem, Vol. 1, No.1, (2013) 60 -68.

[6] I. V. Br. Tamba, Skripsi: Pengaruh Dosis dan Lama Fermentasi Tepung Ampas Kelapa (Cocos Nucifera L.) oleh Aspergillus Niger dan Ragi Tape Terhadap Kualitas Nutrisi Pakan, Progam Studi Peternakan, Fakultas Pertanian, Universitas Sumatera Utara, Medan, 2016.

[7] Jayanudin, A. Z. Lestari, Nurbayanti, Pengaruh Suhu dan Rasio Pelarut Ekstraksi Terhadap Rendemen dan Viskositas Natrium Alginat dari Rumput Laut Cokelat (Sargassum sp), J. Integ. Proses, Vol. 5, no. 1, (2014) pp. 51-55.

[8] J. B. Russell, General Chemistry, McGaw-Hill Book Co, Singapore, 1981.

[9] L. D. Sijabat, Skripsi: Pembuatan Papan Partikel Berbahan Dasar Sabut Kelapa (Cocos Nucifera L.) Progam Studi Keteknikan Pertanian, Fakultas Pertanian, Universitas Sumatera Utara, Medan, 2016.

[10] L. Sutiyono dan Edahwati, Pemanfaatan Kulit Kemiri untuk Pembuatan Arang
Aktif dengan Cara Pirolisis, Jurnal Penelitian Ilmu Teknik, Vol. 6 No. 2, (2006) 135-136.

[11] M. Yuniwati, A. W. Kusuma, F. Yunanto, Optimasi kondisi proses ekstraksi zat pewarna dalam daun suji dengan pelarut etanol, Prosiding Seminar Nasional Aplikasi Sains Teknologi, Periode III ISSN 1979-911X, 2012, pp. 257-263.

[12] M. Y. Ritonga, D. H. Sihombing, A. R. Sihotang, Pemanfaatan Abu Kulit Buah Kelapa sebagai Katalis pada Reaksi Transesterifikasi Minyak Sawit Menjadi Metil Ester, Jurnal Teknik Kimia USU, Vol.2 No.4, (2013) 18.

[13] S. Prasetyo, H. Sunjaya, Y. Yanuar, Pengaruh Rasio Massa Daun Suji/ Pelarut, Temperatur dan Jenis Pelarut pada Ekstraksi Klorofil Daun Suji secara Batch dengan Pengontakan Dispersi, Lembaga Penelitian dan Pengabdian Kepada Masyarakat, No. III/LPPM/201202/09-P, 2012.

[14] T. Ismandari, L. Hakim, C. Hidayat, Supriyanto dan Y. Pranoto, Pengeringan Kacang Tanah (Arachis Hypogaea,L) Menggunakan Solar Dryer. Prosiding Seminar Nasional Teknik Pertanian, Yogyakarta, 2008.

[15] T. K. Sitorus, Skripsi: Pengaruh Penambahan Silika Amorf dari Sekam Padi terhadap Sifat Mekanis dan Sifat Fisis Mortar, Departemen Fisika, Universitas Sumatera Utara, Medan, 2009.

[16] T. Prameswari, Skripsi: Sintesis Membran Kitosan-Silika Abu Sekam Padi Untuk Dekolorisasi Zat Warna Congo Red, Jurusan Kimia FMIPA Universitas Negeri Semarang, 2013. 